\title{
What's the difference between a hedge fund and a mutual fund?
}

\author{
Douglas R McKay MD MBA FRCSC ${ }^{1}$, Daniel A Peters MD MBA FRCSC ${ }^{2}$
}

$\mathrm{T}$ he financial industry continually reinvents itself. A significant part of that process involves the creation of investment vehicles aimed at making money for both the people who create them and the people who buy them. Hedge funds are an investment vehicle that has received a fair bit of press over the past few years. What is the difference between a hedge fund and a mutual fund from the perspective of the lay investor? What they share in common is that both are a fund of pooled assets. By working in aggregate, investors are able to realize greater absolute gains. They differ in their philosophical approach to investment, their tolerance for risk, and the manner by which they are regulated by governments through their securities and exchange commissions.

\section{WHAT'S OLD IS NEW AGAIN}

The suggestion that hedge funds are new is erroneous. Hedge funds first came in to existence in their initial iteration in the raging markets of the 1920s, just before one of the most notorious market crashes at the end of that decade. Although the modern hedge fund may vary drastically in its structure from its forefathers and peers, a study of the investment philosophy and an understanding of the premise behind hedging serves as a great stepping stone to understanding some of the more sophisticated investment approaches available to an investor, and the basic concepts and terminology that lie at their root.

\section{"I LIKE TO HEDGE MY BETS"}

Everyone is intuitively familiar in theory with the meaning of this everyday expression. How exactly does that premise weave its way into a pooled asset investment? Hedging in the markets is a way of limiting risk. In one sense, you can think of a hedge as a form of insurance. An investor or fund manager makes a wager that a stock is going to go up. There is no guarantee this will happen and, to limit the downside of the wager, he or she makes another wager to limit exposure to loss.

Everything comes at a price. The cost of mitigating the risk of loss through hedging lies in the limits the hedge puts on profit. You may not lose as much if things go bad, but you also will not make as much if things go well.

Most investors have their impressions of hedge funds formed by stories in the lay press. Hedge fund managers are portrayed as the super-elite of the extravagantly wealthy who garner enormous bonuses as a result of wild double- and triple-digit yearly returns. Make no mistake about it, hedge fund managers do very well, but the high-roller portrait creates a perception that hedge funds are inherently risky. This notion makes it difficult to accept the fact that hedging, in its purest form, is actually a 'conservative' or protective technique. While not every manager is hedging with an aim to conservatism, not every hedge fund is high risk.

\section{HOW ABOUT AN EXAMPLE OF A 'HEDGE'?}

Sometimes an example makes the point. An understanding of hedging also illustrates an understanding of some basic market definitions and investment techniques. To hedge a position, an investor must find another stock that tends to move in the opposite direction of the initial investment through day-to-day market fluctuations.
If you have done your research and have found a stock that you think will go up over a specific period of time, you must do your homework and find one you believe will go down over that same period of time. Stocks that move together exhibit a high degree of correlation. Those that move in the opposite direction exhibit negative correlation. Investors have applied a scale to that definition, which ranges from -1 to +1 . Stocks that move in perfect synchrony are graded as +1 and those that move in a perfectly opposite direction receive a -1 .

Stocks in the same sector tend to move in synchrony (eg, Canadian Pacific and Canadian National railways). Two stocks that exhibit a degree of negative correlation may be an oil producer, such as Exxon, and an airline such as Air Canada. The concept is that if oil prices go up, so will Exxon's share price, but that rise in fuel cost will significantly erode Air Canada's profit and lower that price per share. Managers do not always use stocks to hedge; frequently, resources in the futures market - similar to a barrel of oil or a mineral - can be used, and it doesn't stop there. Anything you can buy and trade and you think will go down can be used as a hedge, including indexes. In fact, after the recent run-up in the markets, some big-league institutional investors are 'shorting' the entire market to hedge their stock purchases. What's 'shorting' you say?

\section{A FEW MORE DEFINITIONS}

Sadly, we need to understand a few more terms before we can move forward with a successful hedge. When most people think of buying stocks, they only think in terms of a stock price rising in value. The goal of investment is, of course, to grow value; however, stocks can go up or down, and either direction represents an opportunity for profit. Therein lies the source of savvy investor profit beyond commission regardless of the market's direction. Gifted investors only flounder when the market is flat. A lack of movement negates an opportunity for profit.

If an investor believes a stock will increase in value, he is said to be going 'long'. If he or she believes the opposite to be true, then he is going 'short', or is 'shorting the investment'. Shorting is not as straight forward as simply believing the investment will drop in value and selling a position. When an investor shorts a security, they are actually selling the investment at its current value without actually ever owning it in the first place. Sound complicated? It sort of is.

To sell something you don't have, you need to get your hands on the security. Enter a broker who will lend you the shares you want to sell from a personal or institutional cache - for a fee and with contractual obligations of return and reimbursement. If you were right and the security falls in value over a prescribed period of time, you can buy it at a lower price than on the day you sold it, repay your debt to the broker and realize the difference as profit.

Sometimes numbers clarify the point. Imagine that you think that stock $A$ is going to drop in value from its current share price of $\$ 10$. If you are confident of that fact, you can short stock A. First you find a broker with acceptable terms who is willing to lend you 10 shares of stock $A$ and you sell it for $\$ 100$ profit. When the price falls to $\$ 6$, you buy 10 shares for $\$ 60$ and repay your debt, realizing a $\$ 40$ gain as profit

${ }^{1}$ Division of Plastic Surgery, Department of Surgery, Queen's University, Kingston; ${ }^{2}$ Division of Plastic Surgery, Department of Surgery and Telfer School of Management, University of Ottawa, Ottawa, Ontario

Correspondence: Dr Douglas R McKay, Division of Plastic Surgery, Department of Surgery, Queen's University, Hotal Dieu Hospital, 166 Brock Street, Brock 3R, B3031, Kingston, Ontario K7L 5G2. Telephone 613-544-3400 ext 2494, fax 613-544-3709,

e-mail mckayd1@kgh.kari.net 
less fees. If stock A climbs to $\$ 12$ per share, you need to buy 10 shares for $\$ 120$ to repay your debt and fulfill your contractual obligation, losing $\$ 20$ plus fees on the exchange.

One can contrast shorting to going long on an investment to ferret out disadvantage. If you imagine a stock will go up in value and it does not, you only lose money if you sell it at less then the original purchase price. Because you own the stock, you can hold it until a point in time in which it climbs in value and potentially still realize a profit. With the 'long' position, the investor still has a security that may have some inherent value at the end of the day. When you short, you don't have the security of the security to fall back on - you don't own anything. When the time comes to repay your investment, you are obligated to repay the debt win or lose. If you are shorting outside of a hedge and ignoring correlation to another security, you are delving into the world of speculation. Speculation is a far riskier game to play.

At a fund level, the hedge fund, in its purest form and original iteration, is comprised of a series of negatively correlated longs and shorts aimed at protecting profit. The sell often used for a hedge fund is that they can match the market highs but protect investors from the downs in the market. Buyer beware, because this is not always the underlying philosophy, and the generic term 'hedge fund' is applied to a wealth of pooled investment strategies. Make sure you read the fine print.

\section{SOUNDS FUN: HOW DO I GET INTO ONE OF THESE HEDGE FUNDS?}

Beyond risk and investment philosophy, hedge funds vary significantly from mutual funds with respect to governmental regulation. To protect investors, the securities arm of the government puts a great deal of regulation on a mutual fund manager. This degree of regulation can significantly limit moves and plays made by the mutual fund manager; a hedge fund manager is not subject to such tight control and can move money in and around in investments in response to changes in the market. The hedge fund can, in theory, be more responsive to unpredictability and major change.

For example, a mutual fund manager is obligated to carry a fully invested portfolio and is limited in the magnitude of movements he or she can make within imposed restrictions. A hedge fund manager, on the other hand, could retreat into a cash position in times of uncertainty to protect wealth and value.
CAN I BUY THESE FROM MY ONLINE BROKER?

Getting into a hedge fund is not as easy as picking up shares of a mutual fund. Because the funds are less regulated, they are only open to accredited investors. This is the government's way of saying 'buyer beware'. An accredited investor is assumed to be more savvy. An accredited investor is assumed to better understand risk. An accredited investor is on his own when an investment sours and cannot cry foul to a regulatory agency.

In Canada, becoming accredited is not as difficult as it sounds. The term would suggest that some test or license is required to achieve status. Although licensed financial advisors are indeed accredited, the easiest way to achieve accreditation is to have lots of money. It is potentially odd to suggest that earning money and having good financial common sense go hand in hand, but the securities commission may simply be suggesting that if you have a good pile of cash in the bank, then you can afford to 'tank' the odd investment. A yearly salary of $\geq \$ 200,000$ is enough to turn a Canadian citizen into an accredited investor. Ditto for a net worth when combined with a spouse or partner of $>\$ 1$ million.

\section{I'D LIKE ONE SHARE PLEASE}

Hedge funds usually have a minimum entry investment that is beyond the reach of the everyday citizen. Some in the media liken them to mutual funds for the rich. Some of Canada's best-known hedge funds carry $\$ 3$ million minimums to get your foot in the door. Neverthless, the average entry point is approximately $\$ 500 \mathrm{~K}$. Hedge funds are rarely marketed directly to the individual consumer, relying on word of mouth in certain social circles. They have become a staple of pension plans of late due to their potential for wealth protection.

Getting in can be a challenge for the average individual and so, too, could getting out. Not all hedge funds will let you liquidate your position on a whim in times of turbulence. On any given market day, a mutual fund share or security owner can sell out a position, but this is not always true for a hedge fund. Some will not let you out for a year while others rebalance monthly and allow for an exit.

Hedge funds are merely another investment vehicle. Similar to any investment, they require research before purchase. If you think this may be for you, be certain to heed the advice of a professional before jumping in, and be certain to read the fine print on the rules of the game. 